https://nv.nltu.edu.ua

https://doi.org/10.15421/40280613

Article received $24.05 .2018 \mathrm{p}$.

Article accepted 25.06.2018 p.

удк 379.85

$@ \bowtie$ Correspondence author

N. Ye. Pankiv

pankiv.natakia@gmail.com

Н. Є. Паньків, М. І. Сеньків

Національний університет "Львівська політехніка", м. Львів, Україна

\title{
СТВОРЕННЯ ЕКОЛОГО-ПІЗНАВАЛЬНОГО ТУРИСТИЧНОГО МАРШРУТУ "ШЛЯХАМИ ГРАФА ВОЛОДИМИРА ДІДУШИЦЬКОГО" У БРОДІВСЬКОМУ РАЙОНІ ЛЬВІВСЬКОЇ ОБЛАСТІ
}

\begin{abstract}
З'ясовано еколого-географічні та історичні передумови створення природного заповідника на території північного Поділля. Проаналізовано сучасний стан НПП "Північне Поділля", зокрема територій комплексної пам'ятки природи місцевого значення "Пам'ятка Пеняцька" і Державного ботанічного заказника місцевого значення "Макітра"; ідентифіковано та проаналізовано біорізноманіття, ландшафтні та історико-культурні особливості цих територій, а також існуючі тут еколого-пізнавальні туристичні маршрути. Охарактеризовано природоохоронну діяльність графа В. Дідушицького, зокрема створення ним природного резервату "Пам'ятка Пеняцька" з метою збереження букового пралісу та охорони місця гніздування рідкісного виду птаха - орлана білохвостого, а також заснування ним Природознавчого музею у Львові. Обгрунтовано доцільність розроблення нового еколого-пізнавального туристичного маршруту на території північного Поділля для продовження природоохоронної діяльності в регіоні, яку започаткував В. Дідушицький. Запропоновано створення дводенного еколого-пізнавального туристичного маршруту "Шляхами графа Володимира Дідушицького" (Львів - Броди - Підкамінь - Пеняки Пліснеське городище - Підгірці - Львів) та докладно охарактеризовано екскурсійні об'єкти, включені до цього маршруту. Проаналізовано значення новоствореного маршруту для збереження цінних природних та історико-культурних комплексів $\mathrm{i}$ об'єктів Бродівщини.
\end{abstract}

Ключові слова: туризм; природа; заповідник; Поділля.

Вступ. Більша частина Бродівського р-ну Львівської обл. розташована на Брідській рівнині, південь якої перетинає низькогірне пасмо Вороняки, яке є частиною Подільської височини. У загальноекологічному аспекті територія північного Поділля, загалом будучи пов'язана 3 Головним європейським вододілом, має виняткове міжнародне значення як територія, на якій формуються витоки таких потужних водних артерій міжнародного значення, як річка Західний Буг, притоки Дністра - річки Золота Липа, Серет, Горинь та притока Дніпра - річка Стир. Збереження екологічної рівноваги такого регіону має винятково важливе значення для забезпечення не лише охорони біорізноманіття флори й фауни, але й загальної екологічної стабільності в західних областях України й на суміжних територіях, зокрема й на територіях суміжних держав.

Викладення основного матеріалу дослідження. Ідея створення заповідника на території північного Поділля з'явилася у XIX ст.: заповідну справу започаткував граф Володимир Дідушицький. Цей шляхетний польський граф українського походження, "Дідух", як він любив себе називати, меценат, колекціонер, політичний діяч, власник Пеняцького маєтку, засновник Природознавчого музею у Львові (Pro muzei, 2018) мав так багато заслуг, що недаремно його удостоєно звання Почесного громадянина міст Львова, Броди, Сокаля та Коломиї. Львівський університет та Краківська акаде- мія присвоїли йому ступінь Почесного доктора та членкореспондента. Неодноразово обрано депутатом до Парламенту у Відні та Галицького сейму, до Львівської міської ради, Головою повітових рад у Бродах і Сокалі. Багато зробив для розвитку економіки, культури, освіти Галичини (Peniaky, 2015).

Найбільше досягнення В. Дідушицького пов'язане зі с. Пеняки (Бродівський р-н Львівської обл.) та Львовом. В. Дідушицький першим в Україні створив заповідник у сучасному розумінні цього слова і назвав новостворений природний резерват "Пам'ятка Пеняцька". Для цього на своїх землях, неподалік власного помістя в с. Пеняки, він виділив 22,4 га 200-річного букового лісу й оголосив їх заповідними у 1886 p. Заповідний природний об'єкт граф Дідушицький створив не для мисливських забав (як тоді практикувалося) чи якихось інших утилітарних цілей, і навіть не 3 релігійних мотивів. Створення резервату "Пам'ятка Пеняцька" заповідалося для збереження букового пралісу, так би мовити, "на всі часи" - для наукових досліджень корінних та рідкісних видів флори і фауни, зокрема для охорони місця гніздування рідкісного виду птаха - орлана білохвостого. На жаль, під час Першої світової війни цей природний резерват було знищено. Резерват "Пам'ятка Пеняцька" був не лише першим природним заповідником на теренах Західної України, але й одним із перших у Європі!

Інформація про авторів:

Паньків Наталія Євгенівна, канд. біол. наук, ст. викладач, кафедра туризму. Email: pankiv.natakia@gmail.com

Сенків Мар'яна Ігорівна, канд. географ. наук, асистент, кафедра туризму. Email: marjankasenkiv22@gmail.com

Цитування за Дсту: Паньків Н. Є., Сеньків М. І. Створення еколого-пізнавального туристичного маршруту "шляхами графа Володимира Дідушицького" у Бродівському районі Львівської області. Науковий вісник НЛтУ України. 2018, т. 28 , № 6. С. 68-73.

Citation APA: Pankiv, N. Ye., \& Senkiv, M. I. (2018). Creation of ecological and cognitive tourist route "by the roads of earl Volodymyr Didushytskyi" in Brody district of the Lviv region. Scientific Bulletin of UNFU, 28(6), 68-73. https://doi.org/10.15421/40280613 
Експонати 3 "Пам'ятки Пеняцької" стали також основою створення графом та подарованого м. Львову Природничого музею - одного з найкращих у Свропі.

Перший період історії "Пам'ятки Пеняцької" завершився у 1914 р., коли під час військових дій Першої світової війни буковий деревостан було сильно порубано. Другий період інтересу до цього об'єкту припадає на кінець 30-х років, коли відомий ботанік Ю. Мондальський (Mądalski, 1936) пропонує відновити охоронний статус, закликаючи пана Голуховського (Gołuchowski), як активного діяча охорони природи та власника тодішньої "Пам'ятки Пеняцької", сприяти цьому. Пропозиції Ю. Мондальського грунтувалися на результатах проведених ним досліджень. Частина території тоді вже було відведено для рубань (Mądalski, 1936). Проте нам достеменно невідомо, чи цю природоохоронну ідею було реалізовано, очевидно, що початок Другої світової війни завадив цьому.

У період між двома Світовими війнами, окрім Ю. Мондальського, досліджували природоохоронні аспекти цієї території В. Шафер (W. Szafer), С. Соколовський (Sokołowski, 1920), Т. Орачевський (Т. Oraczewski) та ін. (Oraczewski, 1921).

Впродовж 1945-1950 pp. корінний деревостан було повністю вирубано. Разом із прадавнім лісом було зруйновано й унікальні водно-болотяні екосистеми регіону як природного, так і антропогенного походження. На цих озерах і ставах у часи заснування "Пам'ятки..." існували унікальні орнітокомплекси, зокрема гніздився орлан-білохвіст (Haliaeetus albicilla) - вид, що зникає в Україні та Європі. Підтвердженням цього є колекції чучел та кладок птахів Державного природознавчого музею НАН України (ДПМ) у Львові, зібрані в околицях с. Пеняки наприкінці XIX ст.

Незважаючи на тотальні рубання, рослинні угруповання колишньої "Пам'ятки Пеняцької" значно відновилися. Насамперед завдяки банку насіння у грунті та добре розвинутим підросту деревних порід і чагарниковому ярусу. Проте не можна повністю відкинути лісовідновлювальні втручання. Наявність ясена звичайного (Fraxinus excelsior L.) та дуба звичайного (Quercus robur L.) в сучасному деревостані "Пам'ятки..." наводить на цю думку.

Природоохоронні заходи були відновлені лише у 1997 р. На місці, де раніше росли 200-літні буки й липи, було виділено 35 га пристигаючого 60-70-річного буково-липового лісу (Львівська обл., Золочівський ДЛГ, Пеняцьке лісництво, квартал № 60, виділ 1) і створено (відновлений) заказник місцевого значення "Пам'ятка Пеняцька" (рішення Львівської обласної ради народних депутатів № 26 від 11.02.1997 р.) (Prots, et al., 2004).

На сьогодні комплексна пам'ятка природи місцевого значення "Пам'ятка Пеняцька" з молодим буковим лісом стала основою створення і складовою частиною Національного природного парку "Північне Поділля" (створеного Указом Президента України № 156 від 10 лютого 2010 р. на територіях Бродівського, Буського та Золочівського р-нів Львівської обл.). НПП "Північне Поділля" створено для збереження цінних природних та історико-культурних комплексів і об'єктів північного Поділля, зокрема реліктові екстразональні степові угруповання та букові лісостани, для підтримання екологічної природної рівноваги в регіоні, створення умов для відпочинку та туризму, здійснення науково-дослідних робіт, проведення екологічної освітньо-виховної роботи (storiia parku, 2018a, 2018b).

Інший степовий резерват "Макітра" на території Вороняків створили представники Ліги охорони природи у 1931 р. поблизу с. Суховоля, що в Бродівському р-ні, площа якого сягала 4 га. 31970 р. г. Макітра була пам'яткою природи місцевого значення, а в 1984 р. ii перевели в категорію Державний ботанічний заказник місцевого значення "Макітра" площею 16 га. Сьогодні заказник належить до складу НПП "Північне Поділля".

Територія заказника охоплює схили г. Макітра (343,6 м), де охороняється осередок рідкісної степової рослинності волинського типу на північній частині іiі поширення. Тут зростає велика кількість квітів, лікарських рослин, різних видів трав, зокрема видів, занесених до Червоної книги України, - сон великий, зозулинець шоломоносний, первоцвіт весняний, вовчі ягоди пахучі, любка дволиста.

Поруч розташовані пагорби - цілий кряж, їх називають макітри. Назва цих гір, кажуть, походить від назви старовинного українського посуду - макітри. Дійсно, ці гори здалеку нагадують перевернуті догори дном горщики.

Одна 3 головних цілей заказника - збереження природної краси цієї місцевості. Заказник "Макітра" - це чи не єдине місце в Західній Україні, де збереглася степова рослинність. На вершині гори відкривається захоплююча панорама. Добре видно міста Броди, Радивилів, Підгорецький замок, що потопають у зелені прилеглих сіл (Makitra, 2018).

Загалом, до кінця 1998 р., було визначено 18 природних об'єктів і віднесено їх до природно-заповідного фонду, які згодом становили основу наукового обгрунтування щодо створення Національного природного парку "Північне Поділля".

Створення НПП "Північне Поділля" - це практично продовження справи В. Дідушицького. Сьогодні територія парку охоплює частину фізико-географічних районів Гологір та Вороняків, що спільно з Розточчям та Кременецькими горами формують північно-західний край Подільської височини. Саме ці низькогірні пасма, якими характеризується місцевий рельеф, є окрасою парку. Більшість території "Північного Поділля" знаходиться в межах висот 250-460 м. Найвищі гори тут: Вапнярка (460,8 м) і Високий Камінь (440,4 м). Територія парку розташована в найбільш горбистій і лісистій частині пасма, вздовж якого проходить Головний європейський вододіл. Тут збереглися особливо цінні букові ліси, що зростають на північно-східній межі ареалу. Звідси бере початок р. Західний Буг, несучи свої води в Балтійське море; також витікають річки басейну Чорного моря - Стир, Серет, Іква (Istoriia parku, 2018a, 2018b).

На території НПП "Північне Поділля" поширено понад 200 видів рослин. Тут зростає таємнича папороть гронянка півмісяцева, завдяки якій народилася легенда про цвіт папороті. Можна також побачити підсніжник білосніжний, рідкісні квіти тінистих лісів- орхідеї, довголисту та червону булатки, а також знайти в природному вигляді кущики перистої клокички. У тінистих лісах зростають такі витончені рослини, як: оживаюча лунарія, корніолійська скополія, лісова лілія, яйцеподібні зозулині сльози, дволиста любка (нічна фіалка) та багато інших. Цінністю парку є татарниколистий відкасник, величезні зіркоподібні кошики якого можна по- 
бачити лише на території Західної України та Східної Польщі.

Місцева фауна налічує 127 видів птахів, 41 вид ссавців. Серед них 22 види занесено до Червоної книги України. Варто також зазначити, що НПП "Північне Поділля" важливий з погляду існування мисливських видів тварин. Фауну території парку досліджено не повністю. За останній період виявлено 2 види птахів, що перебувають під загрозою зникнення та включені до Європейського червоного списку, це - могильник і деркач.

Окрім природничої цінності, територія парку значну історико-культурну спадщину. Це, зокрема, пам'ятки "Золотого кільця": замки та храми Львівщини, музей Маркіяна Шашкевича у с. Підлисся та інші пам'ятки культури (Istoriia parku, 2018a, 2018b).

Важливим напрямом діяльності НПП "Північне Поділля" є і рекреаційно-туристична діяльність. Територія національного природного парку "Північне Поділля" знаходиться в межах надзвичайно цікавої області України - Галичини, яка багата на історичні, культурні, археологічні, архітектурні та природні пам'ятки. Туристи можуть поєднувати відвідування замків, монастирів, церков, музеїв із природними окрасами території парку i місцями відпочинку. Рекреаційно-туристична діяльність спрямована на забезпечення місцевих мешканців та гостей краю загальнооздоровчим, культурно-пізнавальним відпочинком методами активного туризму - пішого, лижного, велосипедного, що сприяє формуванню у рекреантів екологічної культури, бережливого та гуманного ставлення до національного природного надбання.

Сьогодні на території НПП прокладено чотири еколого-пізнавальні туристичні маршрути: екологічно-пізнавальний туристичний маршрут "Від городища до городища через колишні села"; екологічно-пізнавальний туристичний маршрут "Маркіянові місця"; екологічнопізнавальний туристичний маршрут "Святогірський" та екологічно-пізнавальний туристичний маршрут "Триніг" (Turystychni marshruty, 2018).

Навесні піша чи велосипедна мандрівка мальовничими територіями НПП "Північне Поділля" схожа на подорож у казкову країну. Для туристів однією із найпривабливіших таких ділянок є лісисте горбогір'я Вороняцького кряжу навколо комплексної геолого-ботанічної пам'ятки природи "Триніг". У барвистому розмаїтті квітів, які тут розквітають ранньою весною, можна бачити печіночниці звичайні, що в народі називають пролісками, анемони дібровні та анемони жовтецеві, ряст проміжний та зірочки жовті. Однак чи не найкрасивішими серед квіткового розмаїття цієї казкової місцевості парку є медунка м'яка. Ї̈̈ синьо-рожевими квітками рясно усипані лісисті схили вершини "Триніг".

Серед інших видів флори, що заслуговують уваги мандрівників, тут зростають і барвисто квітують весною кущі вовчих ягід звичайних, береза темна (цей вид флори внесено до Червоної книги України), а також багатолітні буки, яких, безсумнівно, можна назвати буками-патріархами.

Окрім розмаїття флори, у лісах навколо пам'ятки природи "Триніг" увагу туристів приваблює численна кількість птахів. Тут можна побачити дятла чорного, жовну зелену та лелеку чорну, які внесено до Червоної книги України, синицю довгохвосту, одуда, іволгу, синицю блакитну, які знаходяться під охороною Бернської конвенції. А ще в лісах г. "Тринога" трапляється во- лове очко- один із найменших європейських птахів. Маса тіла цієї пташини становить 9-11 г, довжина - до $10 \mathrm{~cm}$.

Для туристів ентомологів-аматорів на цій території парку безперечно буде цікаво зустріти жука-носорога, який $є$ рідкісним у нашій місцевості, червонокнижного метелика махаона та інших принадливих комах.

Проте найбільшу зацікавленість і дивовижність у туристів цієї території парку викликають віковічні скелі (Skeli, 2014), що є залишками старих гір із глибини Сарматського моря, яке було теплою внутрішньоконтинентальною водоймою й відступило кілька мільйонів років тому, на початку антропогенового періоду. Сьогодні одна із скель має вигляд лагідного звіра, що стоїть на трьох ногах. Звідси й назва "Триніг". На сусідній вершині г. Збараж теж немало скелястого каміння. Одного з кам'яних валунів, що суворо надвисає із вершини гори, мешканці навколишніх сіл називають камінь-кат. У 1923 р. тут видобували каміння й один із валунів придушив каменяра. Про трагедію дев'яностолітньої давності свідчить напис, викарбуваний на кам'яній площині поруч із валуном, якого сьогодні можна бачити на г. Збараж.

Окрім цього, на території комплексної пам'ятки природи "Триніг" Національного природного парку "Північне Поділля" $\epsilon$ ще багато інших неординарних об'єктів дивовижних форм із цікавою історією. Також на цій ділянці парку можна оглянути колишню каменоломню, залишки військових бліндажів періоду Другої світової війни, природні джерела з іскристою прохолодною водицею тощо (Skeli, 2014).

Однак наша мета - створити еколого-пізнавальний туристичний маршрут, який пролягатиме безпосередньо до території резервату "Пам'ятка Пеняцька" та інформуватиме туристів про заповідні території та правила поведінки на природоохоронних територіях, що сприятиме збереженню та відновленню рідкісних видів флори та фауни, тобто буде продовженням природоохоронної діяльності в регіоні, яку започаткував В. Дідушицький. Окрім цього, створення нового туристичного маршруту сприятиме соціально-економічному розвитку регіону.

Назва маршруту - "Шляхами графа Володимира Дідушицького".

Вид туризму: комбінований - автобусний, пішохідний; екологічно-пізнавальний, історико-краєзнавчий, етнографічний.

Район подорожі: Львів, Бродівський р-н Львівської обл.

Період проведення: весна-літо.

Протяжність маршруту - 293 км.

Час проходження: два дні (з ночівлею у м. Львів).

Схема маршруту: Львів - Броди - Підкамінь - Пеняки - Пліснеське городище - Підгірці - Львів.

У перший день туристичний маршрут (рисунок) розпочинається о 8.00 год у м. Львів, звідки відбувається автобусний переїзд (8.00-9.30 год) до м. Броди, де розміщені науково-пізнавальні матеріали про заповідну територію та діяльність відомого галицького мецената, багатого землевласника і великого шанувальника природи графа Володимира Дідушицького. У Бродах передбачено проведення екскурсії в історико-краєзнавчому музеї (10.00-11.00 год), а також оглядової екскурсії 
містом (11.00-12.00 год); обід (12.00-13.00 год) - у ресторані "Шалена Шкварка".

Броди - давній населений пункт, розташований у східній частині Львівської обл. Місто знаходиться на межі українських історичних земель - Галичини, Волині та Поділля. Географічно це територія Малого Полісся, що "впирається" у підніжжя Вороняцького і Кременецького горбогір'їв.

Місто Броди включено до Списку історичних населених місць України як населений пункт, у якому збереглася планувальна система ідеального міста XVII ст. та значна кількість об'єктів історико-культурної спадщини XVII - поч. XX ст.

До Державного реєстру пам'яток архітектури національного значення у Бродах включено три об'єкти, а до списку пам'яток архітектури місцевого значення 29 об'єктів. У місті є шість пам'яток історії, чотири пам'ятки монументального мистецтва та дві пам'ятки археології. Згідно з прийнятим у 2014 р. історико-архітектурним опорним планом Бродів, понад 50 об'єктів включено до рядових історичних будівель та споруд (фонової історичної забудови). Чимало історико-культурних об'єктів міста другої половини XIX - початку XX ст. розташовані у передмістях Бродів - Білі та Червоні казарми, Шваби, Старі Броди - і потребують окремих досліджень краєзнавців та науковців (Istoriia mista, 2018).

Бродівський історико-краєзнавчий музей з 2001 р. $є$ комунальним закладом Бродівської районної ради. Експозиція музею розміщується у семи залах і поділяється на 43 розділи. Фонди музею налічують понад п'ять тисяч експонатів основного фонду та понад чотири тисячі одиниць науково-допоміжного фонду. Щороку музейна колекція доповнюється матеріалами 3 археологічних розкопок, творами сучасного мистецтва, предметами побуту тощо. Експозицію доповнює панорама "Броди XVII-XVIII ст.", мистецькі твори бродівських художників, банерні фотографії з видами пам'яток історії і культури міста i району. При Бродівському історикокраєзнавчому музеї працює музейна бібліотека та виставкові зали, які діють з листопада 1995 року (Korotka istoriia muzeiu, 2018).

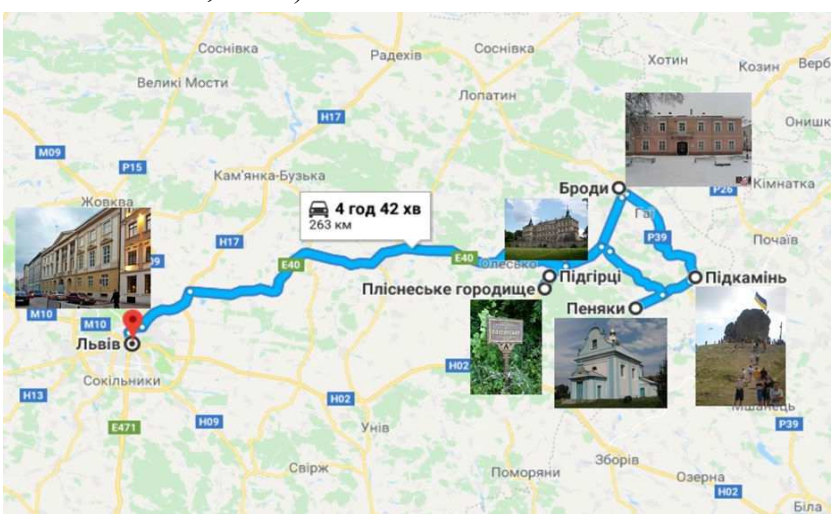

Рисунок. Еколого-пізнавальний туристичний маршрут "Шляхами графа Володимира Дідушицького"

Після обіду відбувається переїзд автобусом (13.0013.30 год) до смт Підкамінь, де протягом 30 хв екскурсанти можуть оглядати місцеву унікальну пам'ятку природи - 16-метрового каменя-останця. Окрім своїх розмірів, "Камінь" привертає увагу тим, що в давні часи на його вершині було збудовано дерев'яну церкву оборонного значення, на зразок карпатських фортець у Тустані та Бубнище. Поряд розташована ще одна історична пам'ятка - монастир "Походження Дерева Хреста Господнього". Щороку в Підкамені проводиться міжнародний етнофестиваль.

3 Підкаменя здійснюється автобусний переїзд (14.00-14.30 год) до с. Пеняки, де передбачено екскурсію (1 год) центральною частиною села.

Село Пеняки простягається за 22 км на південь від Бродів над р. Луг, у широкій котловині поміж двома лісистими хребтами. У Пеняках була чудова магнатська резиденція, яку вважали найбільшою і найкрасивішою в Галичині. Будову палацу з використанням мурів старого замку ініціював Антоні Бєльскі у 70-х роках XVIII ст., а закінчив будівництво наприкінці століття Ігнацій М'янчиньскі. На території колишнього маєтку, що займає тепер центр села, збереглося кілька перебудованих господарських будівель, а також дві опори бічної брами, що провадила колись на подвір'я фільварку. Вдалося врятувати колишню палацову каплицю, що тепер є греко-католицькою церквою Найсвятішої Богородиці. Дивом уціліла також колона Непорочного Зачаття Діви Марії, розташована неподалік від церкви при дорозі.

В іншому кінці села, на захід від центру, при дорозі (якщо їхати на с. Лукавець) стоїть необароковий костел св. Альфонса Родрігеса, збудований у 1924-1926 pр. за проектом Лаврентія Дайчака на місці знищеної святині 3 XVIII ст. Тривалий час святиня була руїною, але зусиллями сільської громади колишній костел вдалося врятувати, і тепер проводиться реставрація. Покинутою залишилася лише цікава дзвіниця, що стоїть біля костелу, на якій лелеки вимостили собі гніздо (Peniaky, 2018).

Після екскурсії Пеняками здійснюється піший перехід безпосередньо до "Пам'ятки Пеняцької", де облаштовано зупинки та створено тимчасові виставки просто неба; час перебування - 16.00-17.00 год.

3і с. Пеняки відбувається автобусний переїзд (17.0018.00 год) до Пліснеського городища, де протягом 30 хв можна оглянути оборонні вали. На хуторі Пліснисько існувало давньоруське городище VIII-XIII ст. На мальовничому пагорбі городища можна відвідати Василіанський монастир XVII-XVIII ст., відчути прохолоду джерельної води, побачити сонячний годинник. Окрім історичних пам'яток, варта уваги г. Менич, геологічна пам'ятка природи місцевого значення, де збереглись відслонення тортонських пісковиків.

Автобусний переїзд до с. Підгірці триває орієнтовно з 18.30 по 18.40 год; тут передбачено екскурсійний огляд зовні Підгорецького замку (тривалість перебування - 30 хв). Підгорецький замок є одним із найкрасивіших ренесансних палаців Європи. Його мури зустрічали феєрверком польського короля Владислава IV та відомого поета Оноре де Бальзака, були у власності іншого монарха Яна III Собєського, ним володіли шляхтичі Жевуські і Сангушки. Розкішний італійський парк, славнозвісні сходи, якими пробігав Михайло Боярський у відомому фільмі "Три мушкетери", середньовічний храм, красиві пейзажі - це все про Підгорецький замок.

3і с. Підгірці відбувається автобусний переїзд до Львова; прибуття - о 20.00 год, опісля - заселення туристів у хостелах і готелях міста.

На другий день туристичного маршруту передбачено збір туристів о 10.30 год біля Львівської Опери; 11.00-13.00 год - екскурсія Державним природознавчим музеєм; 13.00-14.00 год - обід у закладах Львова 
(на вибір туристів); 14.00-17.00 год - оглядова екскурсія містом (пропонуємо туристам відвідати два екскурсійні тури - Малий центр на Чудо-поїзді та Великий центр на Чудо-бусі; протяжність маршруту - 30 км); 17.00-19.00 год - повернення туристів у хостели та готелі, виселення.

Державний природознавчий музей Національної академії наук України - один із найдавніших і найбагатших за науковими природничими фондами серед музеїв Свропи, якого заснував граф В. Дідушицький. У фондах музею зберігаються унікальні експонати - від палеозоологічних колекцій до чудово збережених колекцій земноводних, птахів і тварин XIX ст. (опудала, тушки, яйця тощо). Наукова бібліотека музею нараховує близько 70 тис. томів природничної літератури, починаючи з XVI ст. Відомо, що мама Володимира Дідушицього, Пауліна Дідушицька, збирала гербарії та зберігала колекцію тропічних молюсків. Окрім цього, вона мала талант художника і робила чудові замальовки зібраних експонатів. Коли Володимиру було п'ять років, його тато замовив колекцію мінералів із Польських Татр. 3 часом Володимир почав самостійно займатися колекціонуванням, багато експонатів йому передавали чи привозили 3 мандрівок його друзі. Настав момент, коли природнича збірка зросла настільки, що у домі Дідушицьких на вул. Лисенка вже не вистачало для неї місця. У 1868 р. граф Дідушицький купив для їі зберігання окрему будівлю. Спершу знайомитись 3 експонатами можна було лише раз на тиждень. Згодом граф подарував колекцію місту. Так і з'явився у Львові природничий музей (Про музей...).

Висновки. Загалом відкриття еколого-пізнавального туристичного маршруту "Шляхами графа Володимира Дідушицького" створить умови для організованого відпочинку в природних умовах із дотримуванням режиму охорони природних заповідних територій, що сприятиме збереженню цінних природних та історикокультурних комплексів і об'єктів Бродівщини.

Для інформування населення та природокористувачів про межі заповідних об'єктів, категорію їх заповідання та основні відомості про режим і правила поведінки на природоохоронних територіях, необхідно виготовити та встановити інформаційні щити, інформаційно-охоронні знаки, протипожежні та природоохоронні аншлаги, обмежувальні споруди - шлагбауми та ознакувати еколого-пізнавальний туристичний маршрут "Шляхами графа Володимира Дідушицького".

Для роз'яснення місцевому населенню та відвідувачам парку основної мети і цілей створення природоохоронної установи, основних вимог природоохоронного законодавства, періодично в місцевих засобах масової інформації необхідно публікувати статті відповідної тематики, виготовляти i розповсюджувати буклети та листівки про збереження природи рідного краю.

Важливим напрямом природоохоронної діяльності має бути екологоосвітня робота зі шкільною молоддю для формування у підростаючого покоління бережливого ставлення до природи рідного краю, екологічної культури та мислення. Для популяризації природоохоронної діяльності в регіоні, яку започаткував В. Дідушицький, доцільно проводити наукові форуми, круглі столи, науково-технічні наради, робочі наради з питань екології, рекреації, туризму тощо.

\section{Перелік використаних джерел}

Istoriia mista. (2018). Brodivskyi istoryko-kraieznavchyi muzei. Retrieved from: http://www.brodyhistory.org.ua/istorychnyy-spadok/istoriya-mista.. [In Ukrainian].

Istoriia parku. (2018a). Ofitsiinyi sait NPP "Pivnichne Podillia". Retrieved from: http://park-podillya.com.ua/park. [In Ukrainian].

Istoriia parku. (2018b). Ofitsinyi sait NPP "Pivnichne Podillia". Retrieved from: https://www.karpaty.info/ua/uk/lv/bd/pidhirtsi/sights/podillya. [In Ukrainian].

Korotka istoriia muzeiu. (2018). Brodivskyi istoryko-kraieznavchyi muzei. Retrieved from: http://www.brodyhistory.org.ua/istorykokrayeznavchyy-muzey.. [In Ukrainian].

Mądalski, J. (1936). O wskrzeszenie Pamiątki pieniackiej w okolicach Złoczowa. Ochrona Przyrody, 16, 961-01.

Makitra. (2018). Botanichnyi zapovidnyk Makitra. Retrieved from: http://itinery.com.ua/object/view/botanicheskiy-zapovednikmakitra. [In Ukrainian].

Oraczewski, T. (1921). Rezerwat leśny "Pamiątka w Pieniakach". Sylwan, 39, 123-130.

Peniaky. (2015). Zhyttiepys sela. Brody: Holos vidrodzhennia, 196 p. [In Ukrainian].

Peniaky. (2018). Pamiatky Halychyny. Retrieved from: https://07061989.blox.ua/2010/07/Penyaki.html. [In Ukrainian].

Pro muzei. (2018). Derzhavnyi pryrodoznavchyi muzei. Retrieved from: $\quad$ http://www.smnh.org/ua/muzej/pro-muzej.html. $\quad[\mathrm{In}$ Ukrainian].

Prots, B. H., Chornobai, Yu. M., Vovk, O. B., \& Bokotei, A. A. (2004). Pershyi ukrainskyi rezervat pryrody "Pam'iatka Peniatska": na shliakhu do vidrodzhennia. Naukovi zapysky derzhavnoho pryrodoznavchoho тиzeiu, 20, 1671-1676. [In Ukrainian].

Skeli. (2014). Vikovi skeli ta zhuk-nosorih - v odnomu iz parkiv Lvivshchyny vidkryly sezon aktyvnykh mandriv. 032 UA Sait mista Lvova. Retrieved from: https://www.032.ua/news/496202. [In Ukrainian].

Sokołowski, S. (1920). O potrzebie zakładania rezerwatów leśnych. Ochrona przyrody, 1, 21-24.

Turystychni marshruty. (2018). Ofitsiinyi sait NPP "Pivnichne Podillia". Retrieved from: http://parkpodillya.com.ua/category/turystychni-marshruty. [In Ukrainian].

\section{Н. Е. Панькив, М. И. Сенькив}

Национальный университет "Львовская политехника", г. Львов, Украина

\section{СОЗДАНИЕ ЭКОЛОГО-ПОЗНАВАТЕЛЬНОГО ТУРИСТИЧЕСКОГО МАРШРУТА "ПУТЯМИ ГРАФА ВЛАДИМИРА ДИДУШИЦКОГО" В БРОДОВСКОМ РАЙОНЕ ЛЬВОВСКОЙ ОБЛАСТИ}

Выяснены эколого-географические и исторические предпосылки создания природного заповедника на территории северного Подолья. Проанализировано современное состояние НПП "Северное Подолье", в частности, территорий комплексной памятки природы местного значения "Памятка Пеняцкая" и Государственного ботанического заказника местного значения "Макитра"; идентифицированы и проанализированы биоразнообразие, ландшафтные и историко-культурные особенности этих территорий, а также существующие здесь эколого-познавательные туристические маршруты. Охарактеризована природоохранная деятельность графа В. Дидушицкого, в частности, создание им природного резервата "Памятка Пеняцкая" с целью сохранения буковых лесов и охраны места гнездования редкого вида птицы - орлана белохвостого, а также основание им природоведческого музея во Львове. Обоснована целесообразность разработки нового эколого-познавательного ту- 
ристического маршрута на территории северного Подолья для продолжения начатой графом В. Дидушицким природоохранной деятельности в регионе. Предложено создание двухдневного эколого-познавательного туристического маршрута "Дорогами графа Владимира Дидушицкого" (Львов - Броды - Подкамень - Пеняки - Плиснеське городище - Подгорцы - Львов) и подробно охарактеризованы экскурсионные объекты, включенные в этот маршрут. Проанализировано значение новосозданного маршрута для сохранения ценных природных и историко-культурных комплексов и объектов Бродовщины.

Ключевые слова: туризм; природа; заповедник; Подолье.

N. Ye. Pankiv, M. I. Senkiv

Lviv Polytechnic National University, Lviv, Ukraine

\section{CREATION OF ECOLOGICAL AND COGNITIVE TOURIST ROUTE "BY THE ROADS OF EARL VOLODYMYR DIDUSHYTSKYI" IN BRODY DISTRICT OF THE LVIV REGION}

The ecological, geographical and historical prerequisites for creation of a nature reserve on the territory of Northern Podillya are clarified. Most of the territory of the Brodivskyi District of Lviv Region is located on the Bridska Plain, the south of which crosses the low-mountainous complex of Voroniaky, which is a part of the Podolian Upland. The current state of NNP Northern Podillya, in particular, the territory of the Memo Peniatska Complex Nature Memorial of local importance and Makitra State Botanical Reserve of Local Importance, is analyzed; biodiversity, landscape, historical and cultural features of these territories, as well as the existing ecological and cognitive tourist routes, are identified and studied. The Memo Peniatska Reserve was not only the first natural reserve in the territory of Western Ukraine, but also one of the first in Europe. The Makitra Reserve is the only place in Western Ukraine, where the steppe vegetation is preserved. Today on the territory of the NNP four ecological and cognitive tourist routes are already laid. The nature protection activity of Earl V. Didushytskyi is characterized, in particular, the creation of the Memo Peniatska Nature Reserve to preserve beech forests and protect the nesting site for a rare bird species such as the White-tailed eagle, and also the foundation of the Natural History Museum in Lviv. The expediency of development of a new ecological and cognitive tourist route on the territory of Northern Podillya is justified to continue nature protection activity begun by Earl V. Didushytskyi in the region. The creation of a two-day ecological and cognitive tourist route "By the Roads of Earl Volodymyr Didushytskyi" (Lviv - Brody Pidkamin - Penniaky - Plisnesk - Pidhirtsi - Lviv) is proposed and excursion objects included in this route are described in detail. The importance of newly created route for preserving valuable natural, historical and cultural complexes and objects of Brodivshchyna is analyzed. For promoting of environmental activities in the region, founded by V. Didushytskyi, it is advisable to conduct a number of scientific forums, round tables, scientific and technical meetings, workshops on ecology, recreation and tourism.

Keywords: tourism; nature; reserve; Podillya. 